\title{
IMMUNOLOGICAL DETERMINANTS IN A MURINE MODEL OF TOLUENE DIISOCYANATE-INDUCED ASTHMA
}

\section{DOMINIKA ŚWIERCZYŃSKA-MACHURA ${ }^{1}$, JOLANTA WALUSIAK-SKORUPA², EWA NOWAKOWSKA-ŚWIRTA ${ }^{1}$, JOANNA PIASECKA-ZELGA ${ }^{3}$, RADOSŁAW ŚWIERCZ ${ }^{4}$, and CEZARY PAŁCZYŃSKI ${ }^{1,2}$}

\author{
${ }^{1}$ Nofer Institute of Occupational Medicine, Łódź, Poland \\ Centre of Occupational Allergy and Environmental Health \\ ${ }^{2}$ Nofer Institute of Occupational Medicine, Łódź, Poland \\ Department of Occupational Diseases and Toxicology \\ ${ }^{3}$ Nofer Institute of Occupational Medicine, Łódź, Poland \\ Research Laboratory of Medicine and Veterinary Products in the GMP Quality \\ ${ }^{4}$ Nofer Institute of Occupational Medicine, Łódź, Poland \\ Department of Toxicology and Carcinogenesis
}

\begin{abstract}
Objectives: Diisocyanates (DIC) are highly reactive, low-molecular-weight chemicals which are the leading cause of occupational asthma (OA). The aim of the study was to analyze certain aspects of the pathogenesis of allergic inflammation in the airways induced by toluene diisocyanate (TDI) in an experimental model in mice. Materials and Methods: The experiment was carried out on 50 female BALB/cJ/Han/IMP mice, which were exposed by inhalation (intranasal and in the inhalation chamber) to toluene diisocyanate (2,4-TDI). After the experiment, the bronchoalveolar lavage fluid (BALF) was collected from the animals, and the composition of the induced inflammatory cells, and the concentrations of certain cytokines (IL-4, IL-5, TNF- $\alpha$ ) were evaluated. Results: The total number of cells in BALF of the examined group of mice was significantly higher compared to the control mice. There was also a significant increase in neutrophils and eosinophils in the study group compared to the controls. The number of lymphocytes and macrophages did not differ significantly between the two groups. A statistically significant increase in the level of TNF- $\alpha$ was shown to occur in the group exposed to toluene diisocyanate in comparison to the control group. The concentration of IL-4 increased in the study group, compared to the control one, but the differences did not reach the level of significance, $p>0.05$. Such difference was not observed for IL-5. Conclusions: We developed a murine model of TDI-induced asthma which caused the influx of inflammatory cells like eosinophils and neutrophils in the bronchoalveolar lavage fluid (BALF) in the TDI-treated mice. The increase of the concentration of some proinflammatory cytokines (TNF- $\alpha$, IL-4) in BALF from the exposed mice was also observed.
\end{abstract}

Key words:

Toluene diisocyanate, Occupational asthma, Murine model, Allergic inflammation, Cytokines

Received: April 17, 2012. Accepted: September 28, 2012.

Address reprint requests to D. Świerczynska-Machura, Centre of Occupational Allergy and Environmental Health, Nofer Institute of Occupational Medicine, św. Teresy 8, 91-348 Łódź, Poland (e-mail: mika@imp.lodz.pl). 


\section{INTRODUCTION}

Diisocyanates (DIC) are highly reactive, low-molecularweight chemicals which are the leading cause of occupational asthma $(\mathrm{OA})$. The three major diisocyanates present in the workplace include toluene diisocyanate (TDI), diphenyl-methane diisocyanate (MDI) and hexamethylene diisocyanate (HDI), which are used in the production of polyurethanes [1-4]. Clinically, the symptoms of diisocyanate asthma are similar to those present in allergic asthma, suggesting a common immunopathogenesis, although clinical data have highlighted several important differences, such as a low prevalence of specific IgE antibodies, mixed T-helper (Th) type 1/2 responses and the involvement of CD8 T lymphocytes in diisocyanate OA [5-9].

The development of animal models has been fundamental in furthering the current understanding of the immune mechanisms involved in allergic asthma. The animal model of diisocyanate asthma has been considerably more limited. Data suggest that the murine model is the best experimental model for diisocyanate OA. Mice have a better defined genome compared to guinea pigs and rats and there is a greater availability of immunological reagents and different varieties of transgenic animals [10-12].

The purpose of the present study was to develop a murine model of chemical-induced asthma using toluene diisocyanate (TDI), which involves the intranasal and inhalant challenge with TDI, and to assess the cellular composition of induced inflammation, concentrations of certain cytokines (IL-4, IL-5, TNF- $\alpha$ ) in bronchoalveolar lavage fluid (BALF).

\section{MATERIALS AND METHODS}

\section{Experimental animals}

All specific pathogen-free female BALB/cJ/Han/IMP mice (approximately 15-20 g, 6 weeks old) came from the breeding farm of the Nofer Institute of Occupational Medicine in Łódź. The mice were housed throughout the experiment in a laminar flow cabinet, at stable temperature, $19-20^{\circ} \mathrm{C}, 55-60 \%$ relative humidity, and $12 \mathrm{~h} / 12 \mathrm{~h}$ light/dark cycle. The animals received standard feed and tap water. During the experiment, the body weight, overall health, and behavior of the animals were assessed.

The animals were divided into two groups:

- the control group (16 mice) - they were sensitized and challenged only with the solvent (ethyl acetate/olive oil 1:4),

- the exposed group (32 mice) - they were exposed to 2,4-TDI.

\section{Experimental design}

The experiment consisted of two phases: intranasal administration (I phase) and exposure in the inhalation chamber (II phase).

- I phase - Mice were sensitized by means of intranasal administration of $20 \mu \mathrm{l}$ of 3\%TDI (Sigma, ST. Louis, MO, USA) dissolved in ethyl acetate/olive oil (1:4) once a day for 5 consecutive days according to the method of Scheerens et al. [13] with a 3-week interval.

- II phase - 7 days after the second course of sensitization (day 38), the mice were challenged in a cylindrical chamber (TSE) via the airways with 3\% TDI dissolved in ethyl acetate/olive oil (1:4) for 4 hours per day during 5 weeks. 2,4-TDI aerosol containing a 3\% solution of 2,4-TDI dissolved in a mixture of oil and acetone $(1: 4, v / v)$ was supplied into the inhalation chamber. Each time, during the inhalation exposure, the concentrations of 2,4-TDI, humidity and temperature prevailing in the inhalation chamber were measured. It was assumed that the animals were exposed to 2,4-TDI at the concentration of $20 \mathrm{ppb}$ (approximately $0.14 \mathrm{mg} / \mathrm{m}^{3}$ ).

The control mice were sensitized and challenged using the same protocol, but received only the solvent, ethyl acetate/ olive oil (1:4).

In the last week of the experiment (day 32), the animals were killed and the biological material was collected for further research. 


\section{Sampling and cellular analysis of the bronchoalveolar lavage fluid (BALF)}

Bronchoalveolar lavage (BAL) was performed in mice after the pentobarbital anesthesia. Using an infusion needle (cannula) through the trachea, $3.2 \mathrm{ml}$ of $0.9 \% \mathrm{NaCl}$ was supplied in portions of $0.8 \mathrm{ml}$ followed by gentle suction of each of them with a syringe. There was the volume of recovered fluid. The biological material obtained in this way was subjected to biochemical and morphological evaluation.

The bronchoalveolar lavage fluid was centrifuged at $1200 \mathrm{rpm} / \mathrm{min}$ for $10 \mathrm{~min}$ at $4^{\circ} \mathrm{C}$. Samples of the supernatant were secured and stored at $-70^{\circ} \mathrm{C}$ for further study. Cell pellets were resuspended in $1 \mathrm{ml}$ of PBS (PBS, Sigma, USA), then stained with toluidyn blue and counted in the Bürker's chamber. The total number of cells was determined and converted into $1 \mathrm{ml}$ of recovered fluid.

The remaining suspension preparations were made and then stained by May-Grunwald-Giemsa (MGG) and hematoxylin and eosin (HE). The evaluation of cytological preparations was made by counting 300 non-epithelial cells and classifying them as macrophages, eosinophils, neutrophils, basophils, lymphocytes or monocytes. Counting concentric to the center of the preparation was applied.

\section{ELISA for culture supernatant cytokines.}

The levels of interleukin 4 (IL-4), 5 (IL-5) and tumor necrosis factor-alpha (TNF- $\alpha$ ) (R\&D Systems, Abingdon, UK) were measured in undiluted supernatants of BAL fluid by a sandwich enzyme-linked immunosorbent assay (ELISA) according to the manufacturer's instructions.

Lower limits of detection for TNF- $\alpha$, IL-4 and IL-5 we re $0.36-7.21 \mathrm{pg} / \mathrm{ml}$, less than $2 \mathrm{pg} / \mathrm{ml}$ and less than $7 \mathrm{pg} / \mathrm{ml}$, respectively.

\section{ETHICS}

All experimental procedures were approved by the local Ethical Committee for Animal Experiments.

\section{STATISTICS}

Data are presented as mean \pm SD. Statistical analyses were performed by using the non-parametric Mann-Whitney test (Sigma Stat 3.5). The level of $p<0.05$ was considered significant.

\section{RESULTS}

\section{BALF analysis}

Figure 1 shows the total number of cells in BALF at the end of the experiment.

The experimental group showed an increase in the total cell counts compared to the control group.

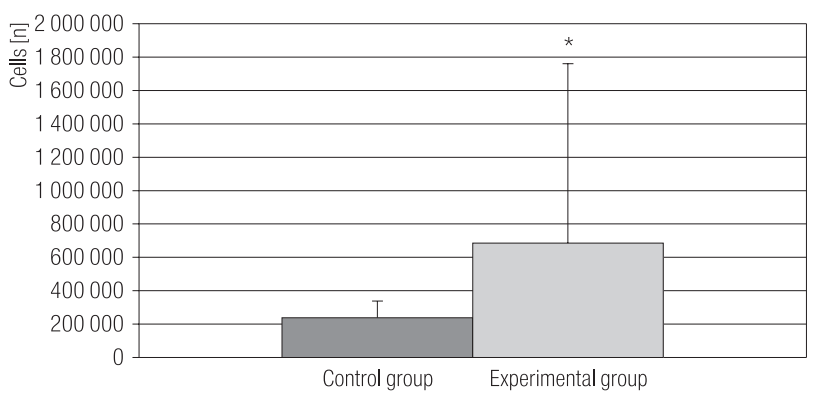

$* \mathrm{p}<0.05$ compared to the control group.

Bars represent mean $\pm \mathrm{SD}$.

Fig. 1. Total cell counts in BALF

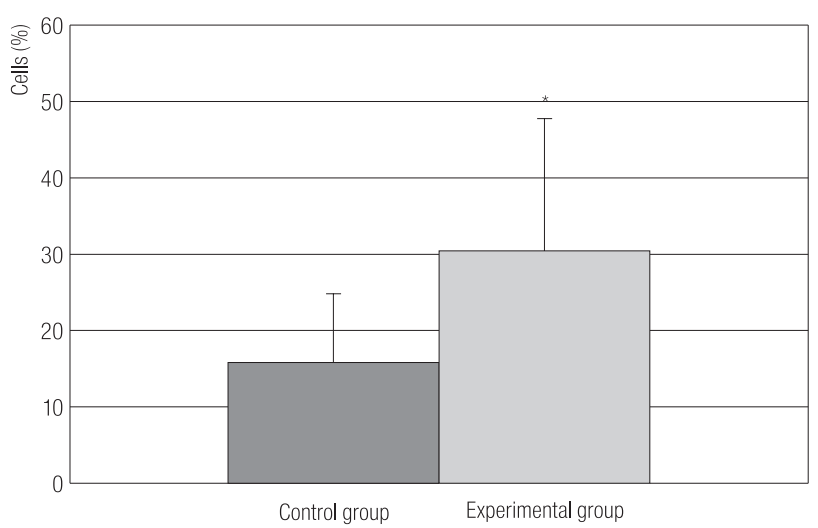

Abbreviations as in Figure 1.

Fig. 2. Neutrophils in BALF 


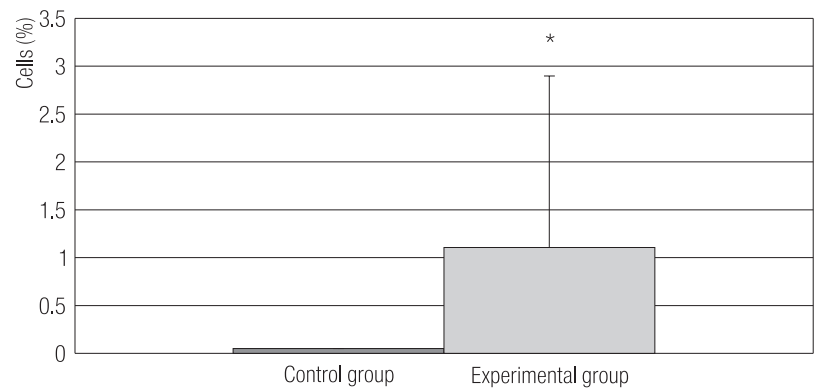

Abbreviations as in Figure 1.

Fig. 3. Eosinophils in BALF

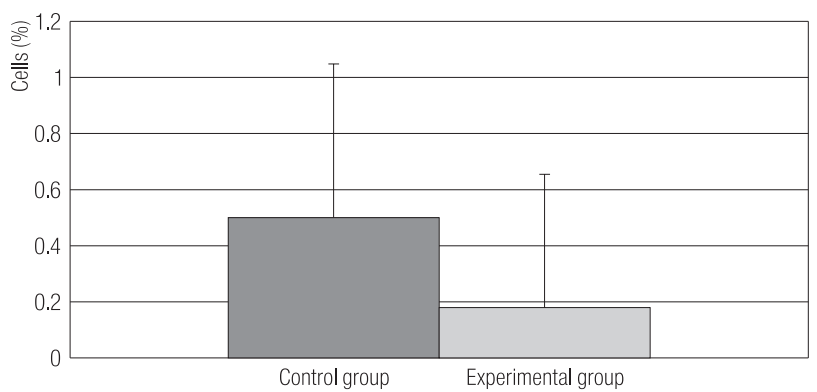

Bars represent mean $\pm \mathrm{SD}$.

Fig. 4. Lymphocytes in BALF

The number of neutrophils and eosinophils were significantly increased in the TDI-challenged group compared to the control one (Figure 3 and 4).

No differences were found in the number of BALF lymphocytes and macrophages in the experimental mice compared to the control mice (Figure 4 and 5).

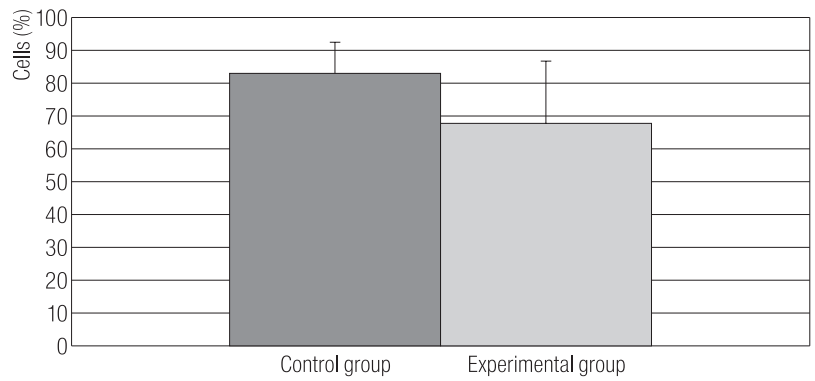

Bars represent mean $\pm \mathrm{SD}$.

Fig. 5. Macrophages in BALF

\section{Cytokine levels in BALF}

Figure 6, 7 and 8 show IL-4, IL-5 and TNF- $\alpha$ concentrations in the BAL fluid. The TDI-challenged mice showed a statistical increase in TNF- $\alpha$ compared to the control mice. The concentration of IL-4 increased in the study

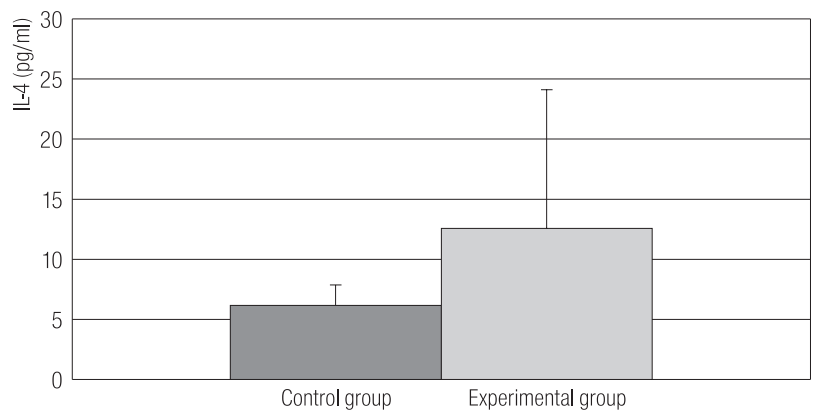

Bars represent mean $\pm \mathrm{SD}$.

Fig. 6. Interleukin 4 levels in BALF

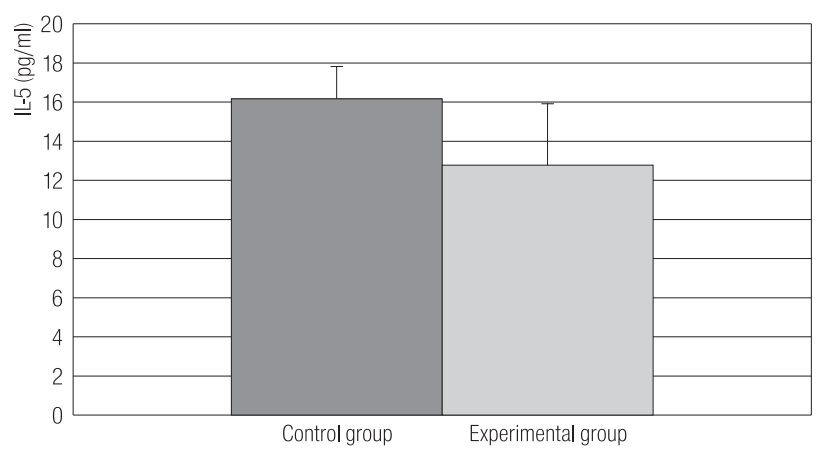

Bars represent mean \pm SD.

Fig. 7. Interleukin 5 levels in BALF

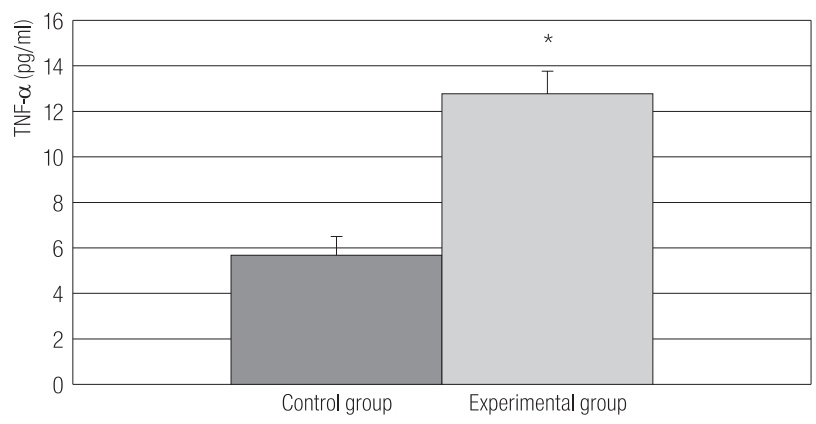

$* \mathrm{p}<0.001$ compared to control group.

Bars represent mean $\pm \mathrm{SD}$.

Fig. 8. Tumor necrosis factor $\alpha$ levels in BALF 
group compared to the control group, but the differences did not reach the level of significance, $p>0.05$. Such difference was not observed for IL-5.

\section{DISCUSSION}

Animal models of disease are invaluable to investigate mechanisms and identify therapeutic targets. Murine models have been extensively used to study atopic asthma. Mouse ovalbumin models have successfully duplicated many features of atopic asthma such as eosinophilic airway inflammation, Th2 $\mathrm{T}$ cell responses and airway hyperresponsiveness [10].

The first animal studies of diisocyanate OA were conducted in guinea pigs, and they demonstrated the acute inhalational toxicity and immunogenicity of diisocyanates. Guinea pig models display many of the clinical features of human diisocyanate-induced OA, including airway hyperresponsiveness (AHR), epithelial injury, neutrophilic inflammation, airway eosinophilia, and a late-phase asthmatic reaction. These studies have also revealed that exposure through skin or airways, common routes of exposure in the workplace, can lead to dermal or respiratory sensitization $[14,15]$.

Early studies using murine models demonstrated the involvement of the immune system in diisocyanate OA, as topical exposure to TDI resulted in the production of TDI-specific IgE antibodies and contact hypersensitivity. It was lately shown that CD4 and CD8 T lymphocytes were important effector cells in these responses. However, these early models lacked the evidence of respiratory inflammation [16-19].

Newer models of murine diisocyanate OA vary greatly in regard to mice strain, the diisocyanate used, the route, timing, and minimum diisocyanate dose required to produce sensitization, as well as the inflammatory and physiologic responses noted.

In this study, we developed a murine model of TDI-induced asthma. We used the intranasal sensitization and respiratory challenge with 3\% TDI. Using our challenge protocol, we showed the infiltration of inflammatory cells, especially neutrophils and eosinophils in BALF. Herrick and colleagues [20] have published a murine model of HDI asthma where BALB/c mice were epicutaneously sensitized with HDI followed by intranasal respiratory challenge with HDI-albumin, resulting in BALF eosinophilia and marked lung inflammation composed of lymphocytes and eosinophils. In the murine model of TDI asthma applied by Lee et al., the intranasal sensitization with TDI followed by the respiratory challenge with ultrasonically nebulized TDI resulted in airway hyperresponsiveness, inflammatory infiltrates around bronchioles, a predominantly neutrophilic response in the BALF [21,22].

In our experiment, we also investigated the role of inflammatory mediators in TDI-induced asthma. Because many features of diisocyanate asthma are similar to atopic asthma, including airway inflammation characterized by activated CD4+ T cells and increased levels of IL-4 and IL-5, we determined the concentrations of those cytokines in BALF. We noted non-significantly increased levels of IL-4 in BALF of the exposed mice compared to the control ones. Surprisingly, the level of IL-5 did not increase.

Numerous data are accessible from works considering the type of immune response and determinants in TDI-induced asthma. Ban et al. [23] described four models of TDI-induced asthma, where the immune-mediated mechanisms depended on the route of administration. Topical application followed by intra-tracheal instillations of TDI resulted in local and systemic Th2-dominated immune responses associated with a rise in IL-4, IL-5 and IL-13. On the other hand, the experimental design, in which TDI was administrated by inhalation only, failed to provoke a vigorous Th2 immune response, with a slight increase in IL-5 production and serum total $\operatorname{IgE}$ [23]. However, other authors have observed the significant increase of Th2 cytokines after inhalation exposure of TDI. 
Mice were exposed to $20 \mathrm{ppb}$ of TDI for 6 weeks, $4 \mathrm{~h}$ per day in an inhalation chamber [24].

In our study, the significant increase of TNF- $\alpha$ in BALF of the TDI-exposed animals as compared to the controls was observed. Earlier reports have shown that TNF- $\alpha$ is a likely central mediator of airway inflammation and bronchial hyperresponsiveness in asthma [25]. Using TNF- $\alpha$-deficient mice, Matheson et al. [26] identified TNF- $\alpha$ as an integral pro-inflammatory cytokine in disease development. Increased levels of airway IL-4 and TNF- $\alpha$ mRNA, predominantly neutrophilic inflammation in BALF and migration of airway dendritic cells to the draining lymph nodes were specifically documented.

In conclusion, we developed a murine model of TDI-induced asthma which simulated the influx of inflammatory cells and the increase of some cytokines in the bronchoalveolar lavage fluid (BALF) in the TDI-treated mice.

The continued use of murine models will enable the pursuit of novel findings from patient-oriented studies. A better understanding of the immunopathogenesis of diisocyanate asthma will hopefully lead to identification of early markers of sensitization and asthma, as well as a better understanding of exposure and risk factors, both of which should greatly facilitate the development of the much-needed diagnostic and preventive strategies for diisocyanate asthma.

\section{REFERENCES}

1. Wisniewski AV, Redlich CA, Mapp CE, Bernstein DI. Polyisocyanates and their prepolymers. In: Bernstein IL, ChanYeung M, Malo JL, Bernstein DI, editors. Asthma in the workplace. 3rd. ed. New York: Taylor and Francis Group; 2006. p. 481-504.

2. NIOSH. Preventing asthma and death from diisocyanate exposure. Cincinnati: Public Health Service, CDC/NIOSH Alert 1996;96-111.

3. Baur X. Occupational asthma due to isocyanates. Lung 1996;174:23-30.
4. Moscato G, Dellabianka A, Maestrelli P, Paggiaro P, Romano C, De Zotti R, et al. Features and severity of occupational asthma upon diagnosis: an Italian multicentric case review. Allergy 2002;57:236-42.

5. Fisseler-Eckhoff A, Bartsch H, Zinsky R, Schirren J. Environmental isocyanate-induced asthma: Morphologic and pathogenetic aspects of an increasing occupational disease. Int J Environ Res Public Health 2011;8:3672-87.

6. Wisniewski AV, Redlich CA. Recent developments in diisocyanate asthma. Curr Opinion Allergy Clin Immunol 2001;1:169-75.

7. Lange RW, Day BW, Lemus R, Tyurin VA, Kagan VE, Karol MH. Intracellular S-glutathionyl adducts in murine lung and human bronchoepithelial cells after exposure to diisocyanatotoulene. Chem Res Toxicol 1999;1:931-6.

8. Raulf-Heimsoth M, Baur X. Pathomechanisms and pathophysiology of isocyanate-induced diseases - summary of present knowledge. Am J Ind Med 1998;34:137-48.

9. Krakowiak A, Pałczyński C, Ruta U, Walusiak J, Wittczak T, Gruchała J, et al. Cellular and biochemical findings in bronchoalveolar lavage from patients with occupational asthma due to diisocyanates. Int Rev Allergology and Clin Immunol 2000;6(2):45-9.

10. Gelfand EW. Pro: mice are good model of human airway disease. Am J Respir Crit Care Med 2002;166(1):5-6.

11. Isenberg-Feig H, Justice JP, Keane-Myers A. Animal models of allergic asthma. Curr Allergy Asthma Rep 2003;3:70-8.

12. Karol MH. Comparison of clinical and experimental data from an animal model of pulmonary immunologic sensitivity. Ann Allergy 1991;66:485-9.

13. Scheerens H, Buckley TL, Muis TL, Garssen J, Dormans J, Nijkamp FP, et al. Long-term topical exposure to toluene diisocyanate in mice leads to antibody production and in vivo airway hyperresponsiveness three hours after intranasal challenge. Am J Respir Crit Care Med 1999;159:1074-80.

14. Ebino K, Ueda H, Kawakatsu H, Shutoh Y, Kosaka T, Nagayoshi $\mathrm{E}$, et al. Isolated airway exposure to toluene diisocyanate results in skin sensitization. Toxicol Lett 2001;121:79-85. 
15. Karol MH, Hauth BA, Riley EJ, Magreni CM. Dermal contact with toluene diisocyanate (TDI) produces respiratory tract hypersensitivity in guinea pigs. Toxicol Appl Pharmacol 1981;58:221-30.

16. Dearman RJ, Moussavi A, Kemeny DM, Kimber I. Contribution of $\mathrm{CD} 4+$ and $C D 8+T$ lymphocyte subsets to the cytokine secretion patterns induced in mice during sensitization to contact and respiratory chemical allergens. Immunology 1996;89:502-10.

17. Dearman RJ, Basketter DA, Kimber I. Variable effects of chemical allergens on serum IgE concentration in mice. Preliminary evaluation of a novel approach to the identification of respiratory sensitizers. J Appl Toxicol 1992;12:317-23.

18. Scheerens H, Buckley TL, Davidse EM, Garssen J, Nijkamp FP, Van Loveren H. Toluene diisocyanate-induced in vitro tracheal hyperreactivity in the mouse. Am J Respir Crit Care Med 1996;154:858-65.

19. Tse CS, Chen SE, Bernstein IL. Induction of murine reaginic antibodies by toluene diisocyanate. An animal model of immediate hypersensitivity reactions to isocyanates. Am Rev Respir Dis 1979;120:829-35.

20. Herrick CA, Xu L, Wisnewski AV, Das J, Redlich CA, Bottomly K. A novel mouse model of diisocyanate-induced asthma showing allergic-type inflammation in the lung after inhaled antigen challenge. J Allergy Clin Immunol 2002;109:873-8.

21. Lee SH, Jang AS, Kwon JH, Park SK, Won JH, Park CS. Mesenchymal stem cell transfer suppresses airway remodeling in a toluene diisocyanate-induced murine asthma model. Allergy Asthma Immunol Res 2011;3(3):205-11.

22. Lee YC, Song CH, Lee HB, Oh J-L, Rhee YK, Park HS, et al. A murine model of toluene diisocyanate-induced asthma can be treated with matrix metalloproteinase inhibitor. J Allergy Clin Immunol 2001;108(6):1021-6.

23. Ban M, Morel G, Langonné I, Huguet N, Pépin E, Binet S. TDI can induce respiratory allergy with Th2-dominated response in mice. Toxicology 2006;218:29-47.

24. Matheson JM, Johnson VJ, Luster MI. Immune mediators in a murine model for occupational asthma: studies with toluene diisocyanate. Toxicol Sci 2005;84:99-109.

25. Oosterhout AJMV, Nijkamp FP. Role of cytokines in bronchial hyperresponsiveness. Pulm Pharmacol 1993;6:225-36.

26. Matheson JM, Lemus R, Lange RW, Karol MH, Luster MI. Role of Tumor Necrosis Factor in toluene diisocyanate asthma. Am J Respir Cell Mol Biol 2002;27:396-405.

This work is available in Open Access model and licensed under a Creative Commons Attribution-NonCommercial 3.0 Poland License - http://creativecommons.org/ licenses/by-nc/3.0/pl/deed.en. 